\title{
9. POLICIES FOR EQUALITY AND EMPLOYABILITY
}

\author{
Consequences for Non-Traditional Students in Sweden
}

The general picture in Sweden, as elsewhere, is that higher education (HE) graduates have better chances to become employed than people with a lower educational level. Sweden has had a long tradition of including non-traditional students into HE by widening access, building new higher education institutions, and upgrading post-secondary education to tertiary education (SOU, 2015; Thunborg \& Bron, 2012). The number of HE graduates has increased dramatically as a result of these changes.

During the recent decade, and in accordance with EU and national policies, issues of employability have become politically important. Fejes (2010) claims, that the shift from employment to employability means a shift in responsibility from society and the labour market towards the individual. HE institutions (HEI) are also seen as responsible for enhancing or developing the appropriate competencies of individual students (SOU, 2015). The match between the supply of educational graduates and the requirements and demands of the labour market has thereby become a market model for measuring HE effects. The policy for widening access of non-traditional students and the policy of employability can, on the one hand, be regarded as two strategies for enhancing social mobility. But, on the other hand, the two policies do not seem to be related to each other. For example, when studying policy documents, we cannot find any special concern for non-traditional students in relation to employability.

Thus, in this article we want to address the relation between issues of equality and employability, especially regarding their consequences for Swedish non-traditional students. Our interest in this question derives from our involvement in the European Erasmus+ project called EMPLOY Enhancing the Employability of Non-Traditional Students in HE in which six countries are taking part (2014-1-UK01-KA203001842-TP).

By non-traditional students we mean, in the broadest sense, under-represented groups participating in HE (Bron \& Lönnheden, 2004). In this chapter as elsewhere (Finnegan, Merrill, \& Thunborg, 2014), when writing about non-traditional students we refer to mature as well as young adult students that are the first in their family to enter HE in Sweden (see Thunborg, Bron, \& Edström, 2012). However, in this text we focus particularly on social class and ethnicity. When writing about social class we refer to parents' educational level as used in Swedish official statistics. When 
using ethnicity, we refer to, on the one hand, students born outside Sweden or with both parents born outside Sweden, which in official statistics are called students with an international background. On the other hand, and in comparison, students with a Swedish background are defined as students born in Sweden or with at least one parent born in Sweden.

In this chapter we present firstly the Swedish policies for both widening access as well as employability. Secondly, we map the participation of non-traditional students in HE with regard to social class and ethnicity based on the official Swedish statistics. Thirdly, we describe the demand and supply for the labour market, and finally analyse the employability from the perspective of nontraditional students.

The way to approach our inquiry and be able to discuss, on the one hand, the match between students' demands and patterns of participation in HE, and on the other, the requirements and demands of the labour market and society, we rely on official Swedish statistics from the Swedish Higher Education Authority for HE (UKÄ, 2013, 2014, 2015) and policy documents from the State authorities (Utbildningsdepartementet, 2012, 2014, 2015).

\section{SWEDISH HIGHER EDUCATION POLICIES CONCERNING WIDENING ACCESS AND EMPLOYABILITY}

In the European comparative reports two perspectives of employability are used for analysing policies of employability in different countries; a competence-based and an employment-based perspective. Employability in Sweden according to these reports is defined from a competence-based perspective, focusing on students' skills in relation to the needs of the labour market and society (Eurydice, 2014; Yorke, 2006). There is, however, no clear definition of employability presented by the UKÄ which is executing the state's policies for HE (formulated by the Ministry of Higher Education). In the UKÄ reports, one way of measuring employability is related to students' establishment in the labour market one to two years after the award of qualifications within the area for the graduate degree (UKÄ, 2013).

From the political point of view, HE is seen as a means for both securing employment opportunities for graduates as well as making society more equal by widening participation. The tradition of widening access for non-traditional students in HE is still a central goal, together with a new emphasis on making HE graduates employable in the labour market. Reforms aiming to widen access began in the 1950, but became a central issue in policy reforms from 1977, 1993 and 2007 (SOU, 2015).

According to the Ministry of Higher Education the supply of HE programmes should be related to both student demands and the needs of the labour market (Utbilningsdepartementet: U2012/6996SAM). Thus, new programmes created by HEIs need to take these two aspects into consideration. In line with this, the Swedish government set up a committee to investigate whether the supply 
of educational programmes are well matched in relation to the demands for quality, from students' perspective and the needs of the labour market, as well as society (Utbildningsdepartementet: Kommittédirektiv, diarienummer: 2014, p. 54). A year later the Government Official Report was ready and named Higher education under twenty years (SOU, 2015, p. 70). An overall conclusion in this report is that the match between students' choices of educational programmes and the needs of the labour market is sufficient, with teacher education as an exception. The report, however, is not covering issues regarding non-traditional students.

\section{INEQUALITIES CONCERNING SOCIAL CLASS AND PARTICIPATION IN HIGHER EDUCATION IN SWEDEN}

Despite the reforms for widening participation in HE, inequalities concerning social class persist. According to UKÄ (2014) students, with parents without third cycle education, are less represented in HE than other students. According to UKÄ (2015):

A total of 44 per cent of those born in 1988 had begun to study in higher education by the age of 25 . But for those with at least one parent with a research qualification (licentiate or doctoral degree) the initial participation rate was considerably higher - 84 per cent. In comparison, a mere 22 per cent of those whose parents had only completed lower-secondary education had begun higher education studies. (UKÄ, 2015, p. 26)

Moreover, there are still social differences relating to the choices of educational programmes (ibid):

A larger proportion of those whose parents have advanced educational qualifications choose long programmes. Some examples are programmes in medicine (where 70 per cent of HE entrants in the academic year of 2011/2012 had parents with advanced educational qualifications, Bachelor's programmes in law (55 per cent) and Master's programmes in engineering (54 per cent). In programmes leading to the award of general qualifications students whose parents have advanced educational qualifications are more likely to study for a Master's degree (50 per cent in the academic year of 2011/2012). (UKÄ, 2014, p. 25)

It is, thus, interesting to find out what programmes students with parents having lower educational level, choose. According to UKÄ (2015) vocational teacher training is considered to have the highest degree of students having parents with a low educational level, namely 47 per cent of the students. Even pre-school teacher training has a high proportion of students with parents having a low educational level, thus 41 per cent.

However, it should be added that vocational teachers are already non-traditional as they worked as craftsman and skill workers before applying to HE. 


\section{INEQUALITIES CONCERNING ETHNICIY REGARDING PARTICIPATIION IN HIGHER EDUCATION IN SWEDEN}

From our analysis of national statistics concerning ethnicity, it appears that the number of students from an international background has increased in the last ten years. The overall differences concerning ethnicity is according to UKÄ (2015) small with 41 per cent of those with an international background, i.e. students born in another country than Sweden or with both parents born outside Sweden, compared to 44 per cent of students born in Sweden and with both or at least one parent born in Sweden. However, in an earlier report we claimed that there are differences between ethnic groups where 55 per cent of the Iranians and 21 per cent of the Somalis had entered HE 2011/2012 (Bron, Thunborg, \& Edström, 2014, p. 63). Thus, ethnicity cannot be regarded as a general category.

When considering the participation rate of students with an international background the dental and health care sector appears to be the common choice for students with an international background. 59 per cent of the students studying dental hygiene, 55 per cent of the dentist students and 49 per cent of the students studying biomedical laboratory science have another ethnical background than Swedish (UKÄ, 2015, p. 8). However, there are few students with an international background in programmes for becoming physiotherapists ( 5 per cent), economists (10 per cent), lawyers (11 per cent), psychologists (11 per cent), and architects (12 per cent) (SOU, 2015, p. 106).

\section{THE MATCH BETWEEN SUPPLY AND DEMANDS FOR THE LABOUR MARKET AND SOCIETY}

According to the overall figures concerning unemployment in Sweden, HE graduates have better chances to become employed than people with a lower educational level. The unemployment rate amongst people with higher education level is 5 per cent compared to 7, 5 per cent of those with upper secondary school and almost 21 per cent of people lacking an exam from upper secondary school (www.ekonomifakta.se). In the statistics provided by the UKÄ (2014), 78 per cent of those graduating from HE 2009/10 had established themselves in the labour market in 2011. One question that could be asked is whether the graduates from HE match the demands of the labour market.

UKÄ (2015) presents a prognosis concerning the relation between demands and supply in different occupational areas and claims that there seems to be needs within the health care sector, educational sector and the engineering sector in the future. There are, however different reasons, according to UK $\ddot{A}$, for these shortages (2013):

In a number of these programmes, mainly in the health sector, the shortage is due to a lack of places on offer. Other programmes have places for more students but there are not enough interested applicants. The shortage of many different kinds of qualified teachers is likely to persist, unless more students choose these programmes. (ibid, p. 4) 
Art, journalism, humanities, human resources (HR) and behaviour science, natural science and economics are according to UKÄ (2015) educational areas where there are too many students in relation to labour market needs. There are probably two reasons for that. Firstly, the labour market is not valuing, art and humanities. Secondly, journalism, HR and behavioural science as well as economics are popular educational programmes and thereby have too many applicants.

A conclusion about the match between supply and demands of the labour market is that non-traditional students are applying for educational programmes with good prognosis of getting employment. Thereby they are going to have good chances on the labour market and be able to fill the gaps between demand and supply on the labour market in the future.

\section{DISCUSSION}

In this chapter we have addressed the relation between issues of equality and employability, especially regarding their consequences for Swedish non-traditional students.

By relying on the official statistics and policy documents, we have discussed the employability of non-traditional students in Swedish higher education with a special interest relating to social class and ethnicity. Still, our interest has been focused on the match between patterns of participation for non-traditional students in HE, and the needs and demands of the labour market and society.

On the one hand, and in the overall picture, stated in HE policies as well as national official statistics, the market model built on the match between students' choices of educational programmes and the needs of the labour market is seen as sufficient with a few exceptions. Non-traditional students to a larger extent also seem to help to fill the gap and fulfil the labour market needs by choosing HE programmes related to the education and health care sectors. On the other hand, though, and as a result of our analysis, it seems like HE is becoming a means for a segregated labour market rather than an arena for equality and social mobility. Students having parents with higher education level to a larger extent participate in high status educational programmes such as medicine, engineering and law. However, they also to a larger extent participate in general academic programmes, both at Bachelor and Master levels for getting a unique individual competence to compete on the labour market. They, thereby, enhance their own employability which is in accordance with the new demands claimed in the shift towards employability (Fejes, 2010). Non-traditional students become gapfillers on the labour market, where students with parents having low educational level chose to become pre-school teachers and vocational teachers and students with international background health and dental care workers. Despite widening access to higher education there are still inequalities in regards to participation. That nontraditional students choose programmes highly demanded by the labour market, could be a consequence of wanting to secure their employment, but at the same time also contributing to a lack of social mobility among non-traditional graduates. 
What happened then to the policy of equality in Swedish higher education? It seems like the market forces have taken over the policy of equality. In accordance with the concept of employability, individuals are responsible for their own choices, and unconsciously choose such areas that contribute to segregation on the labour market and in society at large. Moreover, non-traditional students prepare themselves to stay at the lower social stratification level despite gaining higher education graduation, thus not contributing to advance their own social mobility. Fine professions and general programmes are still chosen by the middle and upper classes, while these which have lower demand and lower social status still by socially disadvantaged. This is a paradox of opening access to HE when the market forces steer students' choices, and not only in relation to employment.

\section{A NEED FOR MORE RESEARCH}

Even if there are studies concerning students' employability in Sweden, and their transition between HE and working life generally (see Nyström, Abrandt Dahlgren, \& Dahlgren, 2010; Reid, Dahlgren, Petocz, \& Abrandt-Dahlgren, 2008; Johansson, Hård af Segerstad, Hult, Abrandt Dahlgren, \& Dahlgren, 2007; Johansson, Kopciewicz, \& Dahlgren, 2008; Nilsson \& Nyström, 2013; Haake \& Löfgren Martinsson, 2009; Johansson, 2008; Ohlsson, 2009) there seems to be a lack of studies interested in non-traditional students specifically. In a previous European project (RANLHE) we were concerned with the access and retention of non-traditional students but without looking at the issues of employability (Bron, Thunborg, \& Edström, 2014; Thunborg, Bron, \& Edström, 2012; Edström, 2009). There is, thus, a need for further studies regarding the employability of non-traditional students in higher education and their experiences of the transition to the labour market. We hope that the EMPLOY project will help to contribute to research concerning the employability of non-traditional students and graduates.

\section{REFERENCES}

Bron, A., \& Lönnheden, C. (2004). Higher education for non-traditional students in Sweden: A matter of inclusion. Journal of Adult and Continuing Education, 7, 175-188.

Bron, A., \& Thunborg, C. (2015). Sweden: State of the art in regards to employability of non-traditional students and graduates (EMPLOY report).

Bron, A., Thunborg, C., \& Edström, E. (2014). Ethnicity and class matters: Experiences in Swedish higher education. In F. Finnegan, B. Merrill, \& C. Thunborg (Eds.), Student voices on inequalities in European higher education (pp. 63-73). London: Routledge.

Edström, E. (2009, April 22-24). Wanting to become something: About forming identities in higher education. Paper presented at the third Nordic Conference on adult learning: Communication, collaboration and creativity, University of Southern Denmark, Odense. Retrieved from http://www.ekonomifakta.se/sv/Fakta/Arbetsmarknad/Arbetsloshet/Arbetsloshet-efter-utbildningsniva/

Eurydice Report. (2014). Modernisation of higher education in Europe: Access, retention and employability. Brussels: EC.

Fejes, A. (2010). Discourses on employability: Constituting the responsible citizen. Studies in Continuing Education, 32(2), 89-102. 
Finnegan, F., Merrill, B., \& Thunborg, C. (Eds.). (2014). Student voices on inequalities in European higher education: Challenges for theory, policy and practice in a time of change. London: Routledge.

Haake, U., \& Löfgren Martinsson, M. (2009). Mellan verktygslåda och kritísk reflektion. Om personalvetares anställningsbarhet. In G. Berglund \& A. Fejes (Eds.), Anställningsbarhet: perspektiv från utbildning och arbetsliv. Lund: Studentlitteratur.

Higher Education Act. (1977). Högskolelagen (SFS 1977:218). Stockholm: Utbildningsdepartementet.

Högskoleförordningen. (2014). 2014:1096.

Johansson, K., Hård af Segerstad, H., Hult, H., Abrandt Dahlgren, M., \& Dahlgren, L.-O. (2007). The two faces of political science studies - junior and senior students' thoughts about their education and their future profession. Higher Education, 55, 623-636.

Johansson, K., Kopciewicz, L., \& Dahlgren, L.-O. (2008). Learning for an unknown context: A comparative case study on some Swedish and polish political science student' experiences of the transition from university to working life. Compare, 38(2), 219-231.

Nilsson, S., \& Nyström, S. (2013). Adult learning, education, and the labour market in the employability regime. European Journal for Research on the Education and Learning of Adults, 4(2), 171-187.

Nyström, S., Abrandt Dahlgren, M., \& Dahlgren, L.-O. (2010). A winding road - professional trajectories from higher education to working life: A case study of political science and psychology graduates. Studies in Continuing Education, 30(3), 215-229.

Ohlsson, U. (2009). Vägen in i ett yrke: en studie av lärande och kunskapsutveckling hos nyutbildade sjuksköterskor (Doctoral dissertation). Örebro University, Örebro.

Proposition (2004/05:162). Ny värld - ny högskola [New world - New Higher Education]. Government Bill, Swedish Government, 2004/05:162.

Proposition (2009/10:139). Fokus på kunskap - kvalitet I den högre utbildningen [Focusing knowledge Quality in higher education]. Government Bill, Swedish Government, 2009/10:139.

Reid, A., Dahlgren, L.-O., Petocz, P., \& Abrandt Dahlgren, M. (2008). Identity and engagement for professional formation. Studies in Higher Education, 33(6), 729-742.

SOU. (2015). Högre utbildning under tjugo år. Betänkande av Utredningen om högskolans utbildningsutbud. 2015:70. Stockholm: Regeringskansliet.

Thunborg, C., \& Bron, A. (2012). Higher education and lifelong learning in Sweden. In H. Schutze \& M. Slowey (Eds.), Higher education and lifelong learning. London: Routledge.

Thunborg, C., Bron, A., \& Edström, E. (2012). Forming learning identities in higher education in Sweden. Studies for the Learning Society, 2(2-3), 23-34.

UKÄ. (2013). Higher education in Sweden (2013 Statatus report. Report 2013:3). Stockholm: Swedish Higher Education Authority.

UKÄ. (2014). Higher education in Sweden (Report 2014:10). Stockholm: Swedish Higher Education Authority.

UKÄ. (2015). Universitet och högskolor (University and University Colleges. Årsrapport 2015:8). Stockholm: Swedish Higher Education Authority.

Utbildningsdepartementet. (2012). U2012/6996SAM.

Utbildningsdepartementet. (2014). Kommittédirektiv, diarienummer: 2014:54.

Utbildningsdepartementet. (2015). Promemoria, U2015/1626UH. Retrieved from http://www.ekonomifakta.se

Yorke, M. (2006). Employability in higher education: What it is - what it is not. York: The Higher Education Academy.

\section{Camilla Thunborg}

Stockholm University

Sweden

Agnieszka Bron

Stockholm University

Sweden 